Quarterly Journal of the Geological Society

\title{
On the Jaws of Ptychodus from the Chalk
}

Arthur Smith Woodward

Quarterly Journal of the Geological Society 1904, v.60; p133-136.

doi: $10.1144 / G S L . J G S .1904 .060 .01-04.13$

\section{Email alerting service}

Permission request

Subscribe click here to receive free e-mail alerts when new articles cite this article

click here to seek permission to re-use all or part of this article

click here to subscribe to Quarterly Journal of the Geological Society or the Lyell Collection

\section{Notes}

(C) The Geological Society of London 2014 
Vol.60.] JAWS OF PTICHODIS FROM THE CHAIK.

11. On the Jaws of Prichooc's from the Chalk. By Arthur SMiтh WoopwiRd, LL.D., F.R.S., F.L.S., F.G.S., of the British Museum (Natural History). (Read January 20th, 1904.)

[Plate XV.]

Is $1887^{1}$ I pointed out that the teeth of Ptychodus from the Chalk were arranged in the mouth not like those of the Cestraciont sharks, but rather like those of some of the Myliobatid rays. This arrangement has subsequently been obserred in new specimens, both in England and America." Hitherto, however, no traces of the cartilaginous jaws have been found in association with the dentition, and their shape and relations have thus remained unknown. Quite lately, a new specimen, partly showing the jaws, has been obtained from the Lower Chalk of Glynde by Mr. Henry Willett, and he has kindly submitted it to me for study, to supplement my former description, which was chiefly based on the Willett Collection in the Brighton Museum.

The new fossil evidently belongs to a small variety or young individual of Ptychodus decurrens, the species previously discussed, and its principal characters are shown in the accompanying plate (XV). It comprises fragmentary remains of both jaws, each bearing many of the characteristic teeth arranged in their natural order. The rami of the jaw which may be identified as mandible (Pl. XV, figs. $1 \& 2, m d$ ) are remarkably slender, and meet in an acute angle at the symphysis, which is shown to have been elongated, though it is disintegrated by the formation and oxidation of iron-pyrites. The upper jaw or pterygo-quadrate cartilage (fig. $2, p t q$ ) is represented only by shapeless fragments. The dentition is confined exclusively to the symphysial region, where the teeth are arranged in the usual parallel antero-posterior rows.

Of the lower teetb, some are preserved in natural order above the hinder part of the symphysis, while a few are scattered in front on the decomposed anterior end of the jaw. Of the large median series (iig. 2, o), three teeth are exhibited, displaying all the typical characters of $P$. decuriens. To the left of these are teeth of four paired lateral series $(1-1 v)$ in natural arrangement; while a very small displaced tooth (v) seems to represent a fifth series at the extreme outer border. It is to be observed that the dentition does not curve backward at the side to spread along the mandibular ramus, although the more laterally-placed teeth exhibit the usual slight oblique distortion. If the larger scattered teeth on the symphysis belong to lateral series $\mathrm{I}$, as seems probable, it is also to be

1 'On the Dentition \& Affinities of the Selachian Genus Ptychodus, Agassiz' Quart. Journ. Geol. Soc. vol. xliii (1887) pp. 121-30 \& pl. x.

2 S. W. Williston, 'Cretaceous Selachians \& Prcnodonts' Lniv. Geol. Surv. Kansas, vol. vi (1900) p. $239 \&$ pls. xxr-sxvii. 
Downloaded from http://jgslegacy.lyellcollection.org/ at University of Toronto on August 10, 2014

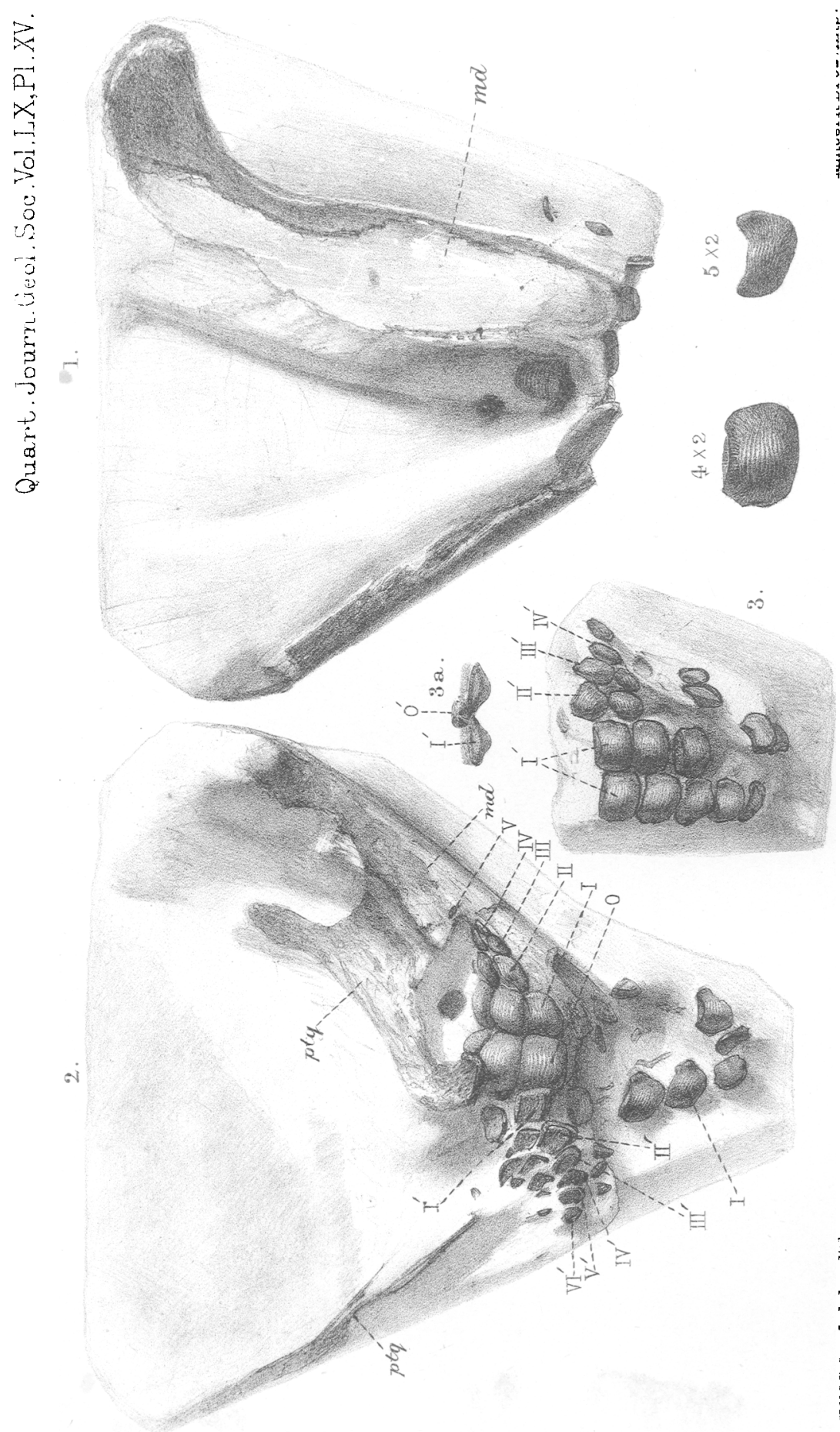


134

[May I 904.

noticed that they exhibit a more decided obliquity, with a smaller median elevation, than the corresponding teeth farther behind. The transverse measurements (in millimetres) of the teeth of the several series at the back of the symphysis are as follows:-0, 8 ; I, $6.5 ; \mathrm{II}, 5$; III, 4 ; IV, $3 ; \mathrm{r}, 2$.

The upper dentition of the right side is partly exposed from its decayed attached face $\left(\mathrm{Pl}\right.$. $\mathrm{XV}$, fig. $\left.2, \mathrm{r}^{\prime}-\mathrm{vI}^{\prime}\right)$, partly seen from its oral

Ptychodus decurrens, Ag.; oral aspect of the mandible of a small variety or young individual, restored matural size; from the Lower Chailh of Glymle (Sussex).

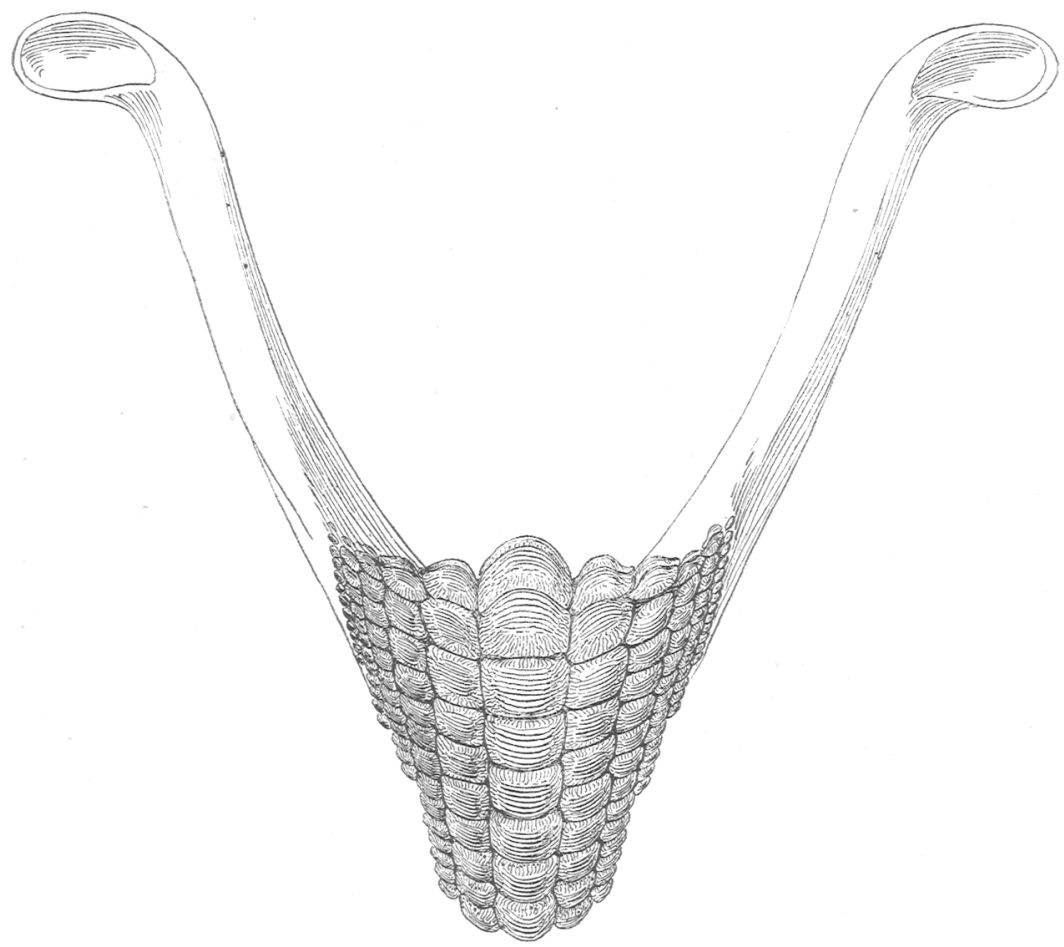

aspect on a detached piece of chalk (fig. 3). The median row of very small teeth is scarcely visible in the fragment just mentioned, the large tceth of the first paired series being crushed together to obscure it, but it is shown in back-riew (fig. $3 a, o^{\prime}$ ). Of the first paired series $\left(I^{\prime}\right)$ three teeth are preserved on the right and six on the left side, all in natural sequence. They are about as large as the teeth of the same series in the opposing jaw. The two or three hindermost teeth (fig. 4) correspond with those ordinarily forming 
this series in $P$. decuriens, but as they are traced forward towards the end of the symphysis, they become shorter in proportion to their width and more obliquely distorted, while their median coronal elevation is smaller (fig. 5). The remaining lateral teeth are more or less displaced, but they are clearly arranged in six paired series altogether (fig. 2); and near the back of the symphysis the teeth have the following transrerse measurements (in millimetres):$\mathrm{o}^{\prime}, 4 ; \mathrm{I}^{\prime}, 6.5$ : II', 5 ; II', 4 ; Iv', $3.5 ; \mathrm{v}^{\prime}, 3$; $\mathrm{vI}^{\prime}$ (?).

The specimen therefore proves that, notwithstanding the powerful nature of the grinding-dentition of Ptychodus and the straightness of its transverse rows, the supporting jaws had not assumed the peculiarly-effective disposition characteristic of the living Myliobatidæ, as I formerly supposed. Although it is quite likely that the angle between the mandibular rami seen in fig. $2(\mathrm{Pl} . \mathrm{XV})$ is slightly altered by accidental distortion, the fossil clearly shows that this cannot have exceeded a right angle. The teeth must thus have been supported by the elongation of the symphysis, of which there is very distinct evidence. This arrangement is peculiar, not to the Myliobatidx, but to the closely-allied Trygonidæ, which have often a powerful dentition. In fact, while Ptychodus is most closely related to the Myliobatidæ by its teeth, as pointed out on former occasions, ${ }^{1}$ it is now shown to resemble the Trygonidæ by its jaws.

The probable explanation of the new discovery is that, in the Cretaceous Period, the great rays of the 'families' Myliobatidæ and Trygonidæ had not become fuliy differentiated. Prof. O. Jækel ${ }^{2}$ has already arrived at suci a conclusion from general considerations, and proposed to place all these fishes in one comprehensive family termed Centrobatidæ. If this arrangement be adopted, Ptychodus represents a primitive sub-family, Pty chodontinæ, which still awaits definition from lack of complete specimens; while the Trygoninæ, Myliobatinæ, and Ceratopterinæ are equivalent subfamilies which survive at the present day.

\section{EXPLANATION OF PLATE XV.}

Ptychodus decurens, Ag.; remains of jaws and dentition, natural size, with two teeth (figs. $4 \& 5$ ) enlarged twice.-Lower Chalk (zone of Holaster subglohosus); Glynde, near Lewes, Sussex. Collection of Henry Willett, Esq. wd $=$ mandible ; $\nu t i=$ upper jaw; $o-v=$ teeth of lower jaw; $0^{\prime}-v_{I}^{\prime}=$ teeth of upper $\mathrm{jaw}$.

Fig. 1. Lower aspect, without symphysis.

2 . Cpper aspect, showing the extent of the decayed symphysis.

3. Part of upper dentition, oral aspect; $3 a$, posterior end-view.

4. Posterior tooth of the upper fir'st paired series, left side.

5. Anterior tooth of the same series.

1 A. S. Woodward, Quart. Journ. Geol. Soc. vol. sliii (1887) p. 129; also Proc. Geol. Assoc. vol. x (1888) pp. 294-98, and ' Catal. Foss. Fishes Brit. Mus.' pt. i (1889) pp. 132-j2.

$\therefore$ 'Die eocanen Selachier vom Monte Bolca' 1894, pp. 115-38. 


\section{Discussion.}

Prof. SeELEY remarked on the great interest of the communication, as establishing the possibility of the existence of an intermediate group between the Sharks and the Rays. The specimen brought forward by the Author showed that, while the dentition in Ptychodus was parallel, the jaws protruded forward in a way nerer observed in typical Rays; and while the teeth of Ptychodus were undoubtedly used for crushing, the jaw was prehensile. 